\title{
Penapisan toleransi kekeringan padi lokal Lampung pada fase perkecambahan
}

Screening of Lampung local rice drought tolerance in germination phase

\author{
Lili Chrisnawati*, Yulianty, Eti Ernawiati, Umilia Fitriyani, Aprilia Eka Putri \\ Jurusan Biologi Fakultas Matematika dan Ilmu pengetahuan Alam Universitas Lampung \\ Jl. Prof. Dr. Ir. Sumantri Brojonegoro Gedong Meneng, Rajabasa, Bandar Lampung City, Lampung 35141 \\ *Email: lili.chrisnawati@fmipa.unila.ac.id
}

Diterima 26 September 2020 Disetujui 11 Desember 2020

\section{INTISARI}

Perkecambahan benih merupakan salah satu tahapan paling kritis dalam pertumbuhan tanaman. Penapisan di tahap ini dapat menjadi informasi awal terhadap toleransi kekeringan. Tujuan penelitian ini adalah mengevaluasi toleransi kekeringan pada padi lokal Lampung varietas Lumbung Sewu Cantik pada fase perkecambahan. Penelitian ini menggunakan Rancangan Acak Lengkap dengan tiga konsentrasi PEG dengan tiga ulangan. Konsentrasi PEG yang diberikan yaitu 0\%, 10\% dan 20\%. Data hasil pengamatan dianalisis ragam pada taraf a uji $=0.05$ dan analisis lanjut menggunakan uji Duncan's Multiple Range Test (DMRT). Hasil pengamatan menunjukkan bahwa semakin tinggi konsentrasi PEG membuat panjang plumulae dan panjang akar seminal padi semakin menurun. Namun, pada radikula, pemberian PEG $20 \%$ tidak menurunkan pertumbuhan panjang. Pemberian PEG dengan konsentrasi 20\% juga tidak membuat berat kering radikula menurun dan pada akar seminal juga tidak ada perbedaan berat yang signifikan antara pemberian PEG konsentrasi 10\% dan 20\%. Hal ini menunjukkan bahwa Padi Lumbung Sewu Cantik memiliki potensi toleran terhadap kekeringan pada fase perkecambahan.

Kata kunci: cekaman kekeringan, padi lokal PEG, perkecambahan

\begin{abstract}
Seed germination is one of the most critical stages in plant growth. Screening at this stage can provide preliminary information on drought tolerance. This study aims to evaluate drought tolerance in local Lampung rice varieties Lumbung Sewu Cantik in the germination phase. This study used a completely randomized design with three concentrations of PEG and three replications. The PEG concentrations given were $0 \%, 10 \%$, and $15 \%$. The observed data were analyzed for variance at the level a test $=0.05$ and further analysis used Duncan's Multiple Range Test (DMRT). The results showed that the higher the PEG concentration, the plumulae length and seminal root length of rice decreased. However, in radicles, PEG $20 \%$ did not decrease length growth. Giving PEG 20\% also did not decrease the dry weight of the radicles and in the seminal roots, there was no significant difference in weight between PEG 10\% and PEG $20 \%$. This indicated that Lumbung Sewu Cantik Padi has the potential to tolerate drought in the germination phase.
\end{abstract}

Keywords: drought stress, germination, local rice, PEG 


\section{PENDAHULUAN}

Tantangan besar yang dihadapi dunia saat ini dan di masa yang akan datang adalah perubahan iklim (climate change) yang disebabkan oleh pemanasan global (global warming). IPCC (Intergovermental Panel on Climate Change) melaporkan bahwa peningkatan suhu rata-rata yang terjadi akhir-akhir ini berdampak pada penurunan produksi pangan global. Sejalan dengan hal tersebut, Furuya dan Kayohama (2005) melaporkan bahwa kenaikan temperatur dapat menyebabkan penurunan produksi padi dunia. Hal ini tentunya menjadi tantangan besar bagi Indonesia, mengingat padi menjadi sumber utama makanan pokok masyarakat.

Cekaman kekeringan merupakan ancaman besar untuk produksi beras di Indonesia. Hal ini disebabkan karena padi (Oryza sativa L.) sangat membutuhkan air selama masa pertumbuhannya. Selain itu, padi yang mendominasi luasan lahan sawah di Indonesia merupakan padi sawah tadah hujan yang sangat tergantung pada ketersediaan air. Ketersediaan air yang kurang akan berpengaruh pada morfologi, anatomi, fisiologi, dan biokimia tanaman (Hammad, 2014) hingga berimbas pada penurunan produksi padi.

Menjawab tantangan akan potensi kekeringan di masa yang akan datang, maka diperlukan strategi yang tepat yang berdampak pada ketahanan pangan jangka panjang hasil interaksi antara adaptasi tanaman dan perubahan iklim. Pengembangan padi yang tahan terhadap cekaman kekeringan adalah salah satu strategi yang dapat dilakukan untuk beradaptasi dengan peningkatan suhu global. Pengembangan padi tahan cekaman kekeringan dapat diawali dengan menggali potensi ketahanan padi lokal (Samidjo, 2017). Lampung memiliki tiga varietas padi lokal yang terdaftar dengan nama Lumbung Sewu Cantik, Sirenik, dan Ampai Merah. Salah satu dari padi lokal tersebut yaitu varietas padi Lumbung Sewu Cantik merupakan padi tahan kering yang banyak dibudidayakan pada dataran tinggi. Selain itu, keunggulan dari padi ini adalah budidaya oleh petani lokal yang dilakukan tanpa pemupukan tetapi mampu menghasilkan $\pm 3,8$ ton/ha GKP (Gabah Kering Panen). Penggalian potensi ketahanan plasma nutfah padi lokal tersebut dapat bermanfaat dalam konservasi sumber daya genetik yang dapat digunakan dalam pengembangan varietas baru tahan cekaman kekeringan.

Pengembangan padi tahan cekaman kekeringan membutuhkan waktu yang lama dan biaya yang besar karena melalui serangkaian tahapan seleksi. Oleh sebab itu, diperlukan metode seleksi cepat yang lebih murah dan efisien untuk mendapatkan informasi awal mengenai genotipe toleran. Penapisan toleransi kekeringan di fase perkecambahan menggunakan PEG menjadi salah satu cara yang sering digunakan (Widyastuti et al., 2016). PEG bersifat mempertahankan potensial osmotik sehingga dapat digunakan sebagai pembatas kadar air pada medium perkecambahan (Widoretno, 2011). Seleksi pada tahap perkecambahan benih dan pertumbuhan bibit sangat penting karena merupakan salah satu tahapan paling kritis sehingga kekeringan dapat menjadi pembatas pertumbuhan tanaman (Faisal et al., 2019).

Penggunaan PEG (Poly Ethylene Glycol) dengan bobot molekul 6000 telah banyak digunakan pada penelitian pengaruh cekaman air terhadap pertumbuhan tanaman (Verslues et al., 2006, Purbajanti et al., 2018, Sawitri et al., 2018). Hal tersebut karena pada konsentrasi tertentu PEG 6000 dapat memberikan kondisi kekeringan seperti pada lahan kering (Mirbahar et al., 2013). Pada penelitian ini dilakukan evaluasi terhadap perkecambahan padi lokal Lampung varietas Lumbung Sewu Cantik terhadap cekaman kekeringan menggunakan konsentrasi PEG 10\% dan $20 \%$. Tujuan penelitian ini adalah untuk mengetahui potensi toleransi kekeringan pada padi lokal Lampung varietas Lumbung Sewu Cantik pada fase perkecambahan.

\section{MATERI DAN METODE}

\section{Material}

Material penelitian ini adalah benih padi lokal Lampung varietas Lumbung Sewu Cantik. Benih 
diperoleh di daerah lereng bukit Kecamatan Pardasuka Kabupaten Pringsewu Lampung.

\section{Sterilisasi Benih}

Benih dipilih yang mempunyai ukuran seragam, lalu dioven selama 72 jam pada suhu $43^{\circ} \mathrm{C}$ untuk menghindari kontaminasi mikroorganisme yang dapat merusak benih.

\section{Perkecambahan dan Pemberian Cekaman Kekeringan}

Benih kemudian direndam selama 24 jam, dan dikecambahkan selama dua hari sampai muncul plumula dan radikula $\pm 2 \mathrm{~mm}$. Sebanyak 20 kecambah yang memiliki ukuran plumula dan radikula yang seragam dipindahkan ke kertas stensil yang telah dibasahi larutan PEG 6000 masing-masing $10 \%$ dan $20 \%$. Perkecambahan benih menggunakan metode kertas digulung dan didirikan dalam germinator non elektrik selama 7 hari. Pada hari ke 7 dilakukan pengamatan pada karakter panjang plumula, panjang radikula, panjang akar seminal, berat kering radikula, dan berat kering akar seminal.

\section{Analisis data}

Penelitian ini menggunakan Rancangan Acak Lengkap dengan tiga konsentrasi PEG dengan tiga ulangan. Konsentrasi PEG yang diberikan yaitu $0 \%, 10 \%$ dan 20\%, Data hasil pengamatan dianalisis lanjut menggunakan analisis ragam pada taraf a uji $=0.05$ dan analisis lanjut menggunakan uji Duncan's Multiple Range Test (DMRT). Pengolahan data menggunakan program statistic SPSS 22.

\section{HASIL DAN PEMBAHASAN}

Hasil penelitian terhadap karakter panjang plumula menunjukkan bahwa konsentrasi PEG berpengaruh terhadap panjang plumula. Semakin tinggi konsentrasi PEG yang diberikan maka semakin pendek plumula pada kecambah padi yang tercekam. Hasil uji Duncan (DMRT) memperlihatkan bahwa ketiga kelompok konsentrasi memiliki beda nyata yang signifikan terhadap karakter panjang plumula (Tabel 1).
Pada tanaman yang tercekam kekeringan, tanaman lebih mementingkan pertumbuhan akar dibandingkan dengan peningkatan pertumbuhan lainnya sebagai adaptasi pada kondisi kekurangan air (Nio \& Torey, 2013).

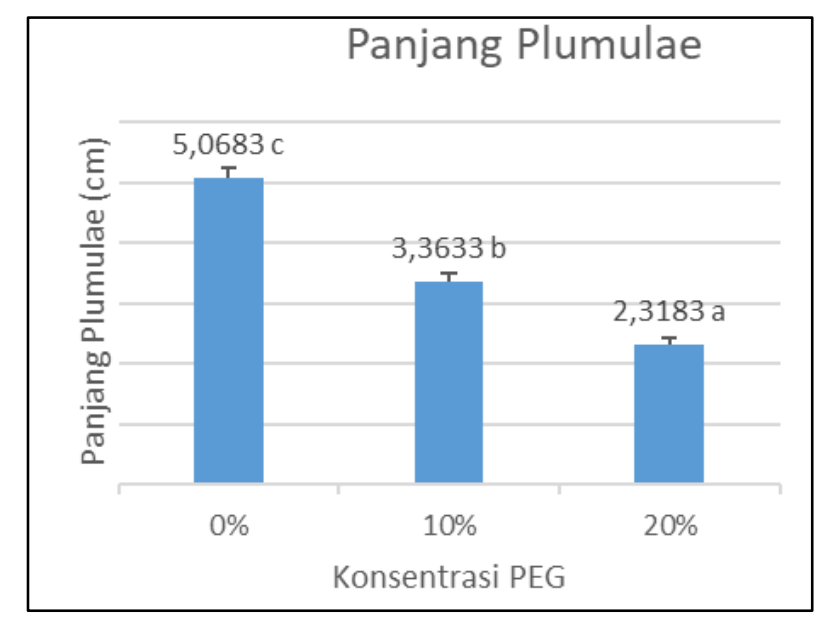

Gambar 1. Rata-rata Panjang plumula pada setiap kelompok perlakuan PEG

Pada karakter panjang radikula (Tabel 2) terlihat bahwa pemberian PEG konsentrasi $10 \%$ membuat panjang akar radikula semakin pendek dibandingkan dengan akar radikula yang tidak diberi PEG. Akan tetapi, hal tersebut tidak terjadi pada pemberian PEG konsentrasi 20\%. Hasil Uji DMRT menunjukkan bahwa pemberian PEG konsentrasi 20\% memiliki panjang akar radikula yang sama (tidak berbeda nyata) dengan akar radikula kelompok kontrol yang tidak diberi PEG.

Panjang akar merupakan karakter morfologi yang banyak diamati pada pengujian toleransi kekeringan. Beberapa hasil penelitian menunjukkan variasi panjang akar pada varietas padi yang diberi cekaman kekeringan (Saha et al., 2019; Abd Allah et al., 2010). Karakter panjang akar dikaitkan dengan ketahanan tanaman terhadap cekaman kekeringan. Akar tanaman yang panjang akan memudahkan tanaman menjangkau sumber air. Padi yang memiliki pemanjangan akar pada pengujian toleransi kekeringan, berpotensi menjadi padi toleran kekeringan (Nio \& Torey, 2013). Pada penelitian ini menunjukkan bahwa akar radikula pada pemberian PEG konsentrasi 20\% lebih panjang dibandingkan pemberian PEG $10 \%$. Hal ini memperlihatkan bahwa kecambah padi Lumbung 
Sewu Cantik dapat beradaptasi pada lingkungan dengan cekaman kekeringan pada skala laboratorium dengan pemberian PEG 6000. PEG menyebabkan penurunan potensial air pada media (Daksa et al., 2014) sehingga dapat digunakan untuk simulasi cekaman kekeringan (Rosawanti, 2015). Pada pemberian PEG dengan konsentrasi $10 \%$, pertumbuhan akar lebih pendek dibandingkan kelompok kontrol, namun pada pemberian konsentrasi $20 \%$ pertumbuhan akar tidak berbeda nyata dengan kelompok kontrol. Hal ini memperlihatkan bahwa pemberian PEG konsentrasi $10 \%$ belum cukup mampu menstimulasi pemanjangan akar sebagai bagian adaptasi pada lingkungan kekeringan dibandingkan pada konsentrasi 20\%. Beberapa penelitian menunjukkan bahwa pemberian PEG konsentrasi 20\%-25\% mampu membedakan genotipe padi yang toleran maupun peka terhadap cekaman kekeringan (Afa, 2012; Meutia et al., 2010). Lumbung Sewu Cantik merupakan padi lokal Lampung yang biasa ditanam pada dataran tinggi yang kering. PEG $20 \%$ memiliki potensial osmotik -0,71 MPa yang setara dengan et al 7,06 bar (Michel \& Kaufmann, 1973) dapat memberikan kondisi kelembaban kritis seperti pada tanah. Tanah pada kondisi kapasitas lapang memiliki potensial osmotik 0,33 bar dan titik layu permanen dengan potensial osmotik 15 bar. Pada titik layu permanen, tanaman sepenuhnya layu yang diikuti kematian karena tidak mampu lagi mengembalikan fungsi turgor dan aktivitas biologisnya. Dengan demikian, potensial osmotik pada PEG $20 \%$ berada pada rentang kelembaban kritis yang masih memungkinkan pertumbuhan akar.

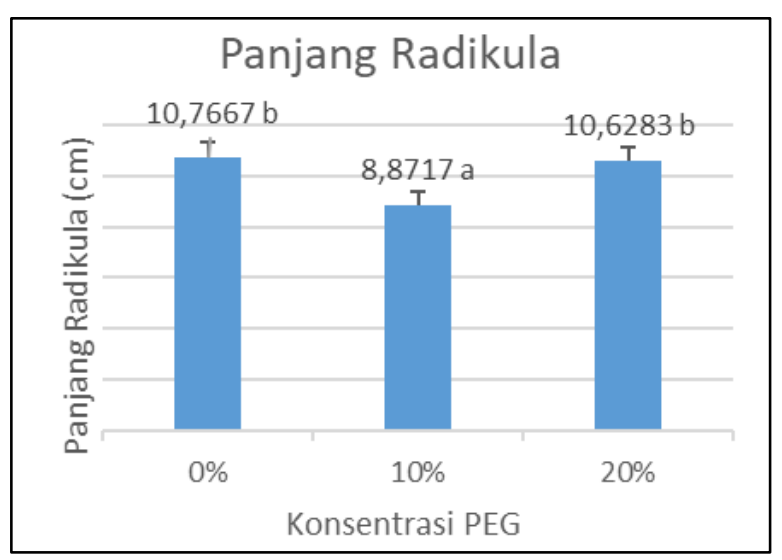

(a)

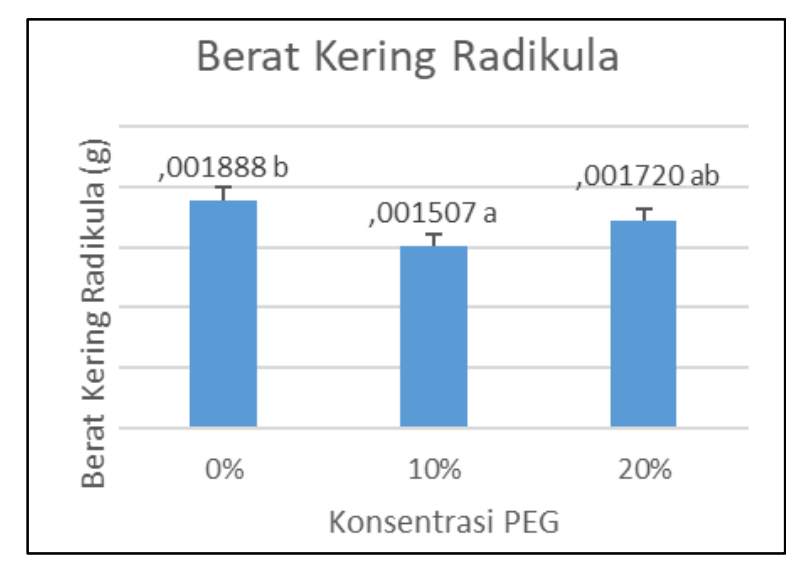

(b)

Gambar 2. Pemangamatan pada radikula pada setiap kelompok perlakuan (a) Rata-rata Panjang radikula; dan(b) rata-rata berat kering radikula.

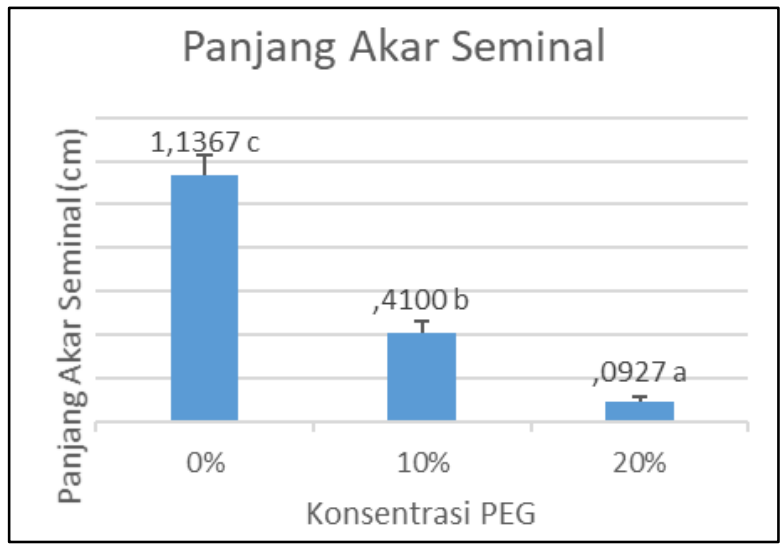

(a)

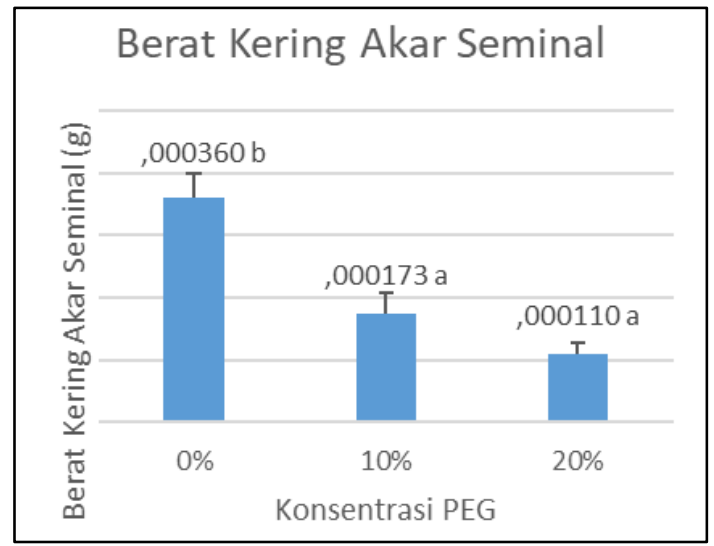

(b)

Gambar 3. Pemangamatan pada akar seminal pada setiap kelompok perlakuan (a) Rata-rata Panjang akar seminal; dan (b) rata-rata berat kering akar seminal. 
Pada karakter berat kering akar radikula (Tabel 3), Pemberian PEG dengan konsentrasi $10 \%$ berpengaruh nyata terhadap penurunan berat kering akar radikula namun pada pemberian PEG dengan konsentrasi 20\%, uji DMRT memperlihatkan dua kelompok subset yang sama dengan kelompok kontrol dan dengan perlakuan PEG 10\%. Cekaman kekeringan dapat menurunkan berat kering akar (Sinaga, 2008) sehingga tanaman dengan berat kering yang besar berpotensi memiliki adaptasi yang baik terhadap kekurangan air (Palupi \& Dedywiryanto 2008). Berat kering akar menggambarkan kepadatan akar yang menentukan respon akar terhadap cekaman kekeringan (Mambani \& Lal, 1983), Kepadatan akar diperlukan untuk menghadapi hambatan hidrolik pada lahan dengan air yang terbatas (Ryser, 2006). Pada penelitian ini, pemberian PEG $10 \%$ menyebabkan berat kering akar radikula mengalami penurunan, namun pada pemberian PEG 20\% berat kering akar sama dengan kelompok kontrol. Dengan demikian, pada potensial osmotik yang tinggi padi Lumbung Sewu Cantik mampu mempertahankan berat kering akar radikula dan berpotensi toleran terhadap kekeringan.

Pada karakter panjang akar seminal, pemberian PEG menyebabkan penurunan panjang akar seminal (Gambar 4). Uji DMRT memperlihatkan perbedaan yang signifikan antara kelompok kontrol dengan kelompok yang diberi cekaman kekeringan. Hasil pengujian memperlihatkan bahwa pemberian PEG konsentrasi 20\% mengakibatkan penurunan panjang akar yang lebih besar dibandingkan pemberian PEG konsentrasi $10 \%$, dengan demikian akar seminal kecambah padi Lumbung Sewu Cantik tidak dapat tumbuh memanjang dengan optimal pada cekaman kekeringan. Pertumbuhan panjang akar seminal yang kurang optimal akan mempengaruhi kedalaman penetrasi akar ke dalam lapisan tanah (Henry et al., 2011) sehingga penyerapan air kurang optimal. Dalam menanggulangi masalah tersebut, Padi Lumbung Sewu Cantik mampu mempertahakan kepadatan akar seminal. Hal tersebut dapat dilihat dari berat kering akar seminal (Gambar 5), yang tidak berbeda nyata antara pemberian PEG $10 \%$ maupun $20 \%$.

\section{SIMPULAN}

Pengujian terhadap perkecambahan padi lokal Lampung Lumbung Sewu Cantik terhadap cekaman kekeringan dengan pemberian PEG konsentrasi $10 \%$ dan $20 \%$ menunjukkan bahwa cekaman kekeringan membuat panjang plumulae dan panjang akar seminal semakin menurun. Namun, pada radikula, pemberian PEG 20\% tidak menurunkan pertumbuhan panjang. Pemberian PEG dengan konsentrasi 20\% juga tidak membuat berat kering radikula menurun dan pada akar seminal juga tidak ada perbedaan berat yang signifikan antara pemberian PEG konsentrasi $10 \%$ dan 20\%. Hal ini menunjukkan bahwa Padi Lumbung Sewu Cantik memiliki potensi toleran terhadap kekeringan pada fase perkecambahan.

\section{KEPUSTAKAAN}

Abd Allah AA, Badawy SA, Zayed B, El-Gohary AA. 2010. The role of root system traits in the drought tolerance of rice (Oryza sativa L.). Journal of Plant Production 1(4): 621631.

Afa L, Purwoko BS, Junaedi A, Haridjaja O, Dewi IS. 2012. Pendugaan toleransi padi hibrida terhadap kekeringan dengan polyetilen glikol (PEG) 6000. J. Agrivigor. 11: 292-299.

Daksa WR, Ete A, Adrianton. 2014. Identifikasi toleransi kekeringan padi gogo lokal Tanangge pada berbagai larutan PEG. J. Agrotekbis. 2: 114-120.

Faisal S, Mujtaba SM, Asma, Mahboob W. 2019. Polyethylene glycol mediated osmotic stress impacts on growth and biochemical aspects of wheat (Triticum aestiyum L.). J. Crop Sci. Biotechnol 22: 213-223.

Furuya J, Koyama O. 2005. Impacts of climatic change on world agricultural product markets: Estimation of macro yield functions. JARQ 39(2): 121-134.

Hammad SAR, Ali OAM. 2014. Physiological and biochemical studies on drought tolerance of wheat plants by application of amino acids 
and yeast extract. Ann. Agric. Sci. 59: 133145.

Henry A, Gowda VRP, Torres RO, McNally KL, Serraj R. 2011. Variation in root system architecture and drought response in rice (Oryza sativa): Phenotyping of the OryzaSNP panel in rainfed lowland fields. Field Crops Res. 120(2): 205-214.

Mambani B, Lal R. 1983. Response of upland rice varieties to drought stress. Plant soil 73:5972.

Meutia SA, Anwar A, Suliansyah I. 2010. Uji toleransi beberapa genotipe padi lokal (Oryza sativa L.) Sumatera Barat terhadap cekaman kekeringan. Jerami 3: 71-81.

Michel BE, Kaufmann MR. 1973. The osmotic potential of polyethylene glycol 6000. Plant Physiol 51(5): 914-6.

Mirbahar AA, Saeed R, Markhand GS. 2013. Effect of polyethylene glycol-6000 on wheat (Triticum aestivum L.) seed germination. Int. J. Biol. Biotech. 10: 401-405.

Nio SA, Torey P. 2013. Karakter morfologi akar sebagai indikator kekurangan air pada tanaman. Bio Logos 3(1): 31-39.

Palupi ER, Dedywiryanto Y. 2008. Kajian karakter toleransi cekaman kekeringan pada empat genotipe bibit kelapa sawit (Elaeis guineensis Jacq). Bul. Agron. 36(1): 24-32.

Purbajanti ED, Kusmiyati F, Fuskhah E, Rosyida R, Adinurani PG, Vincevica-Gaile Z. 2018. Selection for drought-resistant rice (Oryza sativa L.) using polyethylene glycol. IOP Conference Series: Earth and Environmental Science. The 2nd International Conference on Natural Resources and Life Sciences (NRLS-2018) 23-24 August 2018 Vol. 293.

Rosawanti P. 2015. Respon pertumbuhan kedelai (Glycine $\max$ (L.) Merr.) terhadap cekaman kekeringan. Jurnal Daun 2(1): 35-44.

Ryser P. 2006. The mysterious root length. Plant soil 286: 1-6

Sawitri S. 2018. Seleksi beberapa genotipe padi sawah lokal (Oryza sativa L.) terhadap cekaman kekeringan menggunakan polyethylene glycol (PEG) pada fase perkecambahan. Jurnal Agroteknologi 9(1): 23-30.

Saha S, Begum HH, Nasrin S. 2019. Effects of drought stress on growth and accumulation of proline in five rice varieties (Oryza Sativa
L.). Journal of the Asiatic Society of Bangladesh Science 45(2): 241-247.

Samidjo G. 2017. Eksistensi varietas Padi Lokal pada berbagai ekosistem sawah irigasi: studi di daerah istimewa Yogyakarta. Planta Tropica 5(1): 34-41.

Sinaga R.2008. Keterkaitan nisbah tajuk akar dan efisiensi penggunaan air pada rumput gajah dan rumput raja akibat penurunan ketersediaan air tanah. Jurnal Biologi Sumatera 3(1): 29-35

Verslues PE, Agarwal M, Agarwal SK, Zhu J, Zhu JK. 2006. Methods and concepts in quantifying resistance to drought, salt and freezing, abiotic stresses that affect plant water status. The Plant Journal 45(4): 523539.

Widyastuti Y, Purwoko BS, Yunus M. 2016. Identifikasi toleransi kekeringan tetua Padi Hibrida pada fase perkecambahan menggunakan polietilen glikol (PEG) 6000. Indonesian Journal of Agronomy 44(3): 235241.

Widoretno W. 2011. Skrining untuk toleransi terhadap stres Kekeringan pada 36 Varietas Kedelai pada Fase Perkecambahan. Berk Penel Hayati 16:133-142. 